\title{
CASAS ENDEMONIADAS, SANTOS EXORCISTAS E IMÁGenes Que Sudan: El milagro de San Nicolás de Tolentino en Cazalla (1693)*
}

\author{
Haunted houses, holy exorcists and images that sweat: \\ The miracle of St. Nicholas of Tolentino in Cazalla (1693)
}

José Manuel PedrosA**

\section{RESUMEN}

El 12 de septiembre de 1693 sucedió un supuesto milagro en el pueblo de Cazalla de la Sierra (Sevilla). Una imagen de San Nicolás de Tolentino fue llevada en procesión a una casa embrujada que había en el pueblo. Desde aquel día cesaron los fenómenos prodigiosos que se decía que tenían lugar en la casa. Y la imagen del santo sudó aquella noche. Se analizan los testimonios escritos y los paralelos literarios del milagro.

Palabras clave: milagro, Religiosidad popular, casa embrujada, hagiografía, culto de IMÁGENES.

\section{Abstract}

On September 12, 1693, an alleged miracle took place in the town of Cazalla de la Sierra (Seville). An image of St. Nicholas of Tolentino was carried in procession to a haunted house in the village. From that day the prodigious phenomena that were said to have taken place in the house ceased. And the image of the saint sweated that night. The written testimonies and the literary parallels of the miracle are analyzed.

KEYWORDS: MIRACLE, POPULAR RELIGIOSITY, HAUNTED HOUSE, HAGIOGRAPHY, CULT OF IMAGES.

Recepción: 11 de septiembre de 2015.

Dictamen 1: 14 de febrero de 2016.

Dictamen 2: 20 de febrero de 2016.

Dictamen 3: 9 de mayo de 2016.

* Agradezo su ayuda y orientación a José Javier Martínez Palacín, José Luis Garrosa, María Tausiet y Óscar Abenójar.

** Universidad de Alcalá. Correo electrónico: jmpedrosa2000@yahoo.es 


\section{LOS PANES DEL SANTO}

El san Nicolás de Tolentino de carne y hueso nació en Sant'Angelo in Pontano, un pueblo de la provincia de Macerata, en la región italiana de las Marcas, en 1245. Y murió en el pueblo de Tolentino, que está no muy lejos, en la misma provincia, en 1305. Religioso de la orden de los agustinos ermitaños, fue canonizado en 1446. La tradición católica lo ha convertido en uno de los más milagrosos del santoral y le ha atribuido centenares de hechos prodigiosos anteriores y posteriores a su muerte. Es notable que su culto se desarrollara en una tónica de relativa discreción durante la Edad Media y el Renacimiento, y que en la segunda mitad del siglo XVI y en todo del XVII conociera un auge extraordinario. A esa expansión tardía debieron contribuir, primero, el que se tratase de un santo de la poderosa orden agustiniana, muy asociado, por lo tanto, al misionerismo y a la aventura imperialista - muy en particular en América y en Filipinas-, y también el que fuera un santo al que la propia Iglesia católica puso el revelador título de Taumaturgo, palabra a la que el diccionario académico actual asigna las dos únicas y reveladoras acepciones de "mago" y de "persona que practica la magia".

San Nicolás de Tolentino fue, en efecto, una especie de santo-mago, con ribetes esotéricos que causaron fascinación en una época tan rendida a la obsesión demonológica y sobrenatural como fue la barroca. Su leyenda habla, en sintonía con ese sesgo mágico, de la aparición de una estrella que le indicó el camino de Tolentino cuando estaba próximo a morir — reminiscencia de la estrella de los tres Magos evangélicos-. Se le consideraba, además, experto exorcista, resucitador de muertos e intercesor en favor de las almas del purgatorio - lo que le colocaba en una posición de liminalidad con respecto al más allá-. La iconografía lo pinta muchas veces con un sol místico en la mano, o con vestidos y fondos festoneados de estrellas, tal y como todavía hoy se representa tradicionalmente a magos e ilusionistas.

De estas tres maneras es como fue retratado por el gran grabador Marcantonio o Marc-Antoine Raimondi (1480-1534), por el pintor Juan Pantoja de la Cruz (1553-1608) y por un grabador anónimo del XVII: 

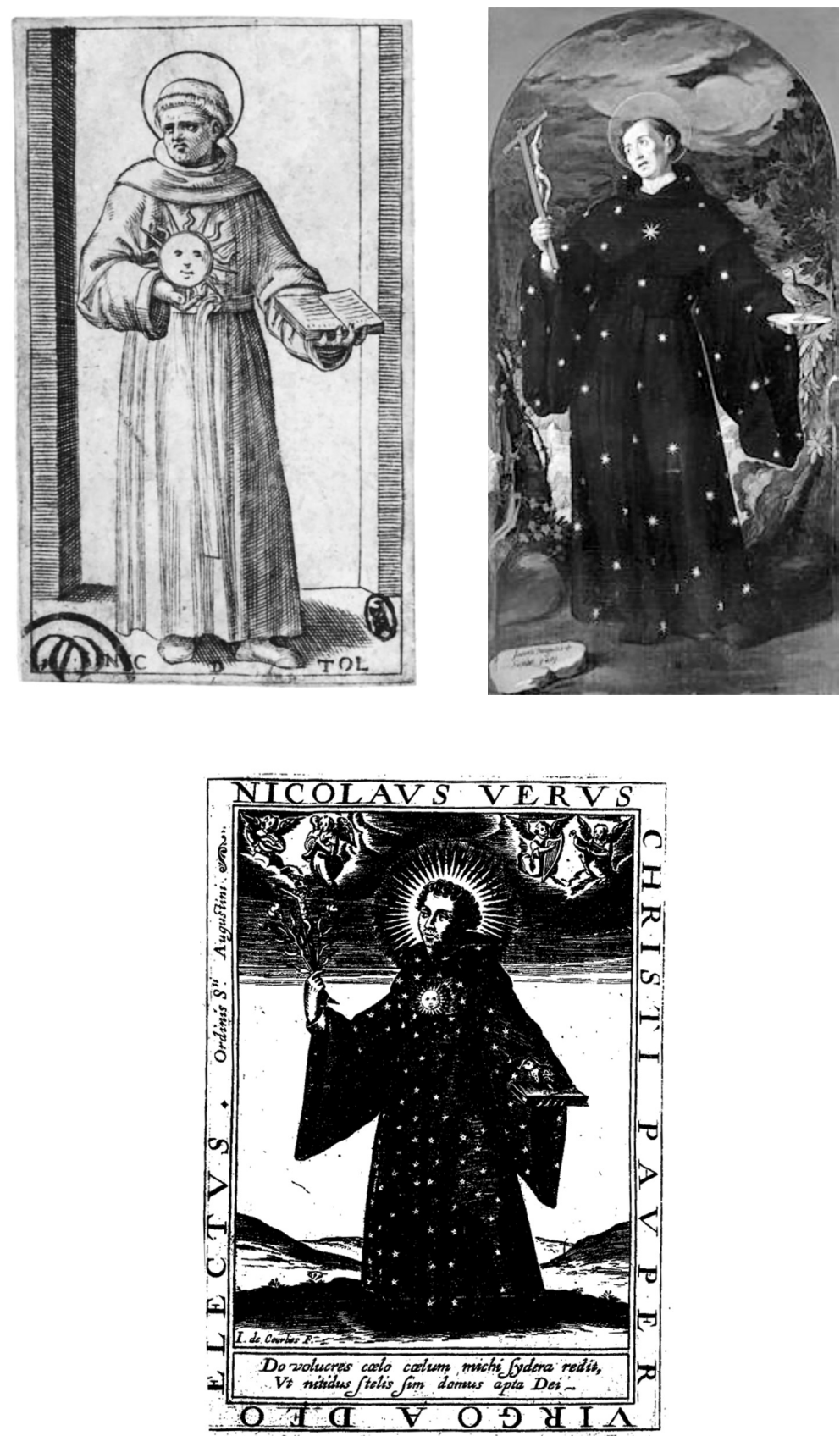
Que san Nicolás de Tolentino fue santo que el pueblo tenía hacia la mitad del siglo XVI como suyo lo prueba la simpática confusión onomástica en que incurrió aquel personaje rústico del Paso de Polo y Olalla, negra, de Lope de Rueda (1992, p. 212): "Eulalla: Pues, a buena fe, que ha sinco noche que fase oración a siñor Nicolás de Tramentinos. Polo: Sant Nicolás de Tolentino querrás dezir".

El caso es que entre los presuntos milagros obrados por el santo, el más celebrado, y uno de los más representativos - porque da muy buena idea de la proyección social que alcanzó su devoción - fue el de los panecillos milagrosos que le habría dado a comer la Virgen para que se recuperase de una enfermedad que parecía mortal. Así evocaba Alonso de Villegas, en su Fructus sanctorum y quinta parte del Flossanctorum de 1594, Discurso 1: 42, el prodigio, que muestra algunas analogías, por cierto, con el celebérrimo milagro del gallo al que hizo resucitar después de asado santo Domingo de la Calzada:

San Nicolás de Tolentino, por treinta años que estuvo en su convento no comió carne, ni huevos, ni peces, ni leche, ni cosas que se hazen de leche. Llegó de una enfermedad a punto de muerte, mandávanle los médicos que comiesse carne porque convenía assí para su salud. Él dezía que era por evitar un daño caer en otro, por evitar la enfermedad del cuerpo, dar en enfermedad de la alma, tomando libertad el apetito para regalarse. El prior, visto que dezían los médicos ser su necessidad de comer carne tan grande, mandóle en virtud de santa obediencia la comiesse. Él dixo que se la truxessen, y es fama que le truxeron una ave guisada y teniéndola en su presencia pidió a Dios que, sin ser él desobediente, hiziesse cómo no la comiesse, y que la ave se levantó viva del plato y se cubrió de plumas, y voló de allícon admiración de los presentes y contento grande del santo, por ver que su abstinencia quedava en pie. Apareciósele a la noche la Madre de Dios con San Augustín y visitóle, diziéndole la Virgen que tomasse un pan y le pusiesse en agua, y comiesse en nombre de Cristo, y sería libre de la enfermedad, como lo fue. Y quedó costumbre en el Orden de San Augustín de bendezir el día deste santo algunos panes que llaman de San Nicolás de Tolentino, y son provechosos para diversas enfermedades, particularmente tercianas. Lo dicho se refiere en su Vida, escrita por un fraile de su Orden, y referido por Surio en el tomo quinto.

Que los panes del santo - que todavía hoy se reparten y se comen en algunos lugares y templos católicos en ocasión de su fiesta - tuvieron fama de muy milagreros lo avala un cronista que en los inicios del XVII informaba de que "la Srma. Infanta está ya con salud, á Dios gracias, y se atribuyó haberle faltado la calentura y cámaras á la intercesion del glorioso San Nicolás de Tolentino, mediante sus 
panecillos, porque tomándolos le faltó el mal, y despues acá está buena” (Cabrera de Córdoba, 1857, p. 226).

De la aclimatación de esta devoción en América y de los poderes varios (desde la sanación de diversas enfermedades hasta la extinción de incendios) que se atribuían a los panes del santo da fe esta otra crónica de 1657 que se refiere a sucesos que se recordaban como supuestamente acaecidos mucho tiempo antes en el Callao, Perú. Se trata de un testimonio lleno de información relevante acerca de la transmisión esencialmente oral y luego escrita de la literatura de milagros en la época:

Solos tres milagros referiré para consuelo de sus devotos, y crédito del Convento. El primero de ellos se conservó muchos años en la memoria de algunos fieles, y por tradición se fue derivando de padres a hijos, hasta que el Padre Maestro Calancha escrivió la Copacavana, donde lo refiere sin año determinado, y sin los nombres de las personas, de la manera que en sustancia lo recibió de la tradición confusa, y es como se sigue. En una víspera de San Nicolás de Tolentino celebravan su fiesta en el Callao sus devotos; alegrando la noche con vistosas luminarias, y fuegos artificiales; entre otros dispararan con descuido un cohete, que extraviado boló hasta la casa de un devoto del santo, y cayó encendido dentro de una caxa de pólvora, que acaso tenía abierta, y puesta a mal recaudo, y en un momento prendió el fuego, y abrazó la casa; creció el incendio, y estando ardiendo con horror de los que la miravan, el afligido dueño perdiendo la esperança de los remedios humanos, acudió a los divinos, yal más eficaz para él, que siempre avía sido la intercessión de San Nicolás, pidiole humilmente socorro, e invocando su nombre, arrojó a las llamas un panecito del Santo, y al mismo instante que cayó en medio de ellas, se apagaron todas, con admiración y gozo grande de los que estavan presentes. Algunos de ellos arrebatados de la devoción, u de la curiosidad se llegaron a la parte donde avían visto caer el panecito, y le hallaron entre las brasas entero sin lesión alguna,y tan blanco como estaba quando le arrojaron al fuego; sacáronle del, y con devotas lágrimas le besaron y pusieron en lugar decente, como a reliquia admirable del Santo. Raro testimonio de la virtud que el Señor depositó en los panecitos de San Nicolás para honra suya, y beneficio de sus fieles devotos (Torres, 1974, pp. 24-25).

Sinuosa pero coherente elipsis, en fin, la que relaciona a una buñuelera barroca - no se olvide que los buñuelos son primos del pan, hijos los dos de arte de elaborar la harina - con la devoción de San Nicolás de Tolentino, según atestiguaba esta noticia que causó revuelo en la corte madrileña en abril de 1661. Es relato que se inscribe, por añadidura, dentro de un tópico narrativo muy perdurable, el de la persona pobre - las leyendas urbanas de hoy suelen convertirla en mendigo- a cuya muerte se le descubre una inmensa fortuna clandestina: 
El Rey Felipe III, de gloriosa memoria, dejó 10.000 misas por su alma, y lunes 30 de Marzo murió una mujer que dejó 9.000 por su alma. Testó de 30.000 ducados. Su ocupación fué hacer y vender buñuelos y aloja, con que ha satisfecho los pesos no cabales; pero anduvo muy cabal en su muerte, porque mandó muchas limosnas y obras pías y que la enterrasen á los pies de San Nicolás de Tolentino, en el Real Convento de San Felipe, lo cual se ejecutó, y esto sin que nadie se lo propusiese, sino por su devocion.

Este día murió tambien la Marquesa de Villafranca. No dejó tantas misas, porque los señores basta serlo; pero aténgome á las misas de la buñuelera (Noticias de la Corte, 1893, pp. 371-372).

No podemos detenernos aquí en el detalle de las propiedades que hasta hoy se siguen atribuyendo a los llamados "panes de San Nicolás" en algunos de los pueblos que celebran al santo. Conformémonos con apreciar este grabado flamenco anónimo (de hacia 1650) que los sitúa en primer plano:






\section{MÁS Literaturas y MÁS MILAgros de SAN NiCOLÁS}

En España fue producida y circuló — sobre todo durante los siglos XVI y XVII, aunque con epígonos que llegaron hasta el XIX - no poca literatura exaltadora de la vida y milagros de San Nicolás de Tolentino. Su devoción estuvo, pues, estrechamente ligada a la cronología y la ideología concretas del Imperio. La composición más destacable de entre todas fue, sin duda, una comedia hagiográfica, bastante desatendida por los críticos, de Lope de Vega. Pero también hubo un ambicioso poema heroico, en veinte libros, que en honor del santo compuso Hernando de Camargo y Salgado: El Santo milagroso augustiniano S. Nicolas de Tolentino, sus excelencias, vida, muerte y milagros (1628).



Fueron impresas, además, algunas hagiografías extensas (Ribera, 1631; Sicardo, 1701) y unos cuantos pliegos y folletos de cordel, algunos traducidos, según consignaban sus títulos, de modelos italianos (Relacion del nvevo prodigio, 1671; Relación distincta, y breve, 1712). En el XVII y el XVIII tales pliegos se acogían sobre todo a la modalidad de las "relaciones de milagros", y en el XIX a la de los "gozos" castellanos y "goigs" catalanes, que se imprimieron muy profusamente en la época. 


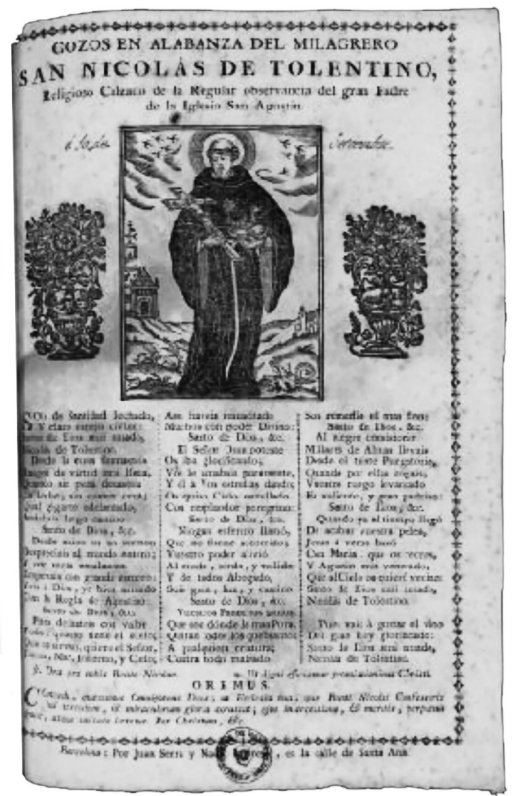

Siglo XVIII, editor Joan Serra y Nadal.

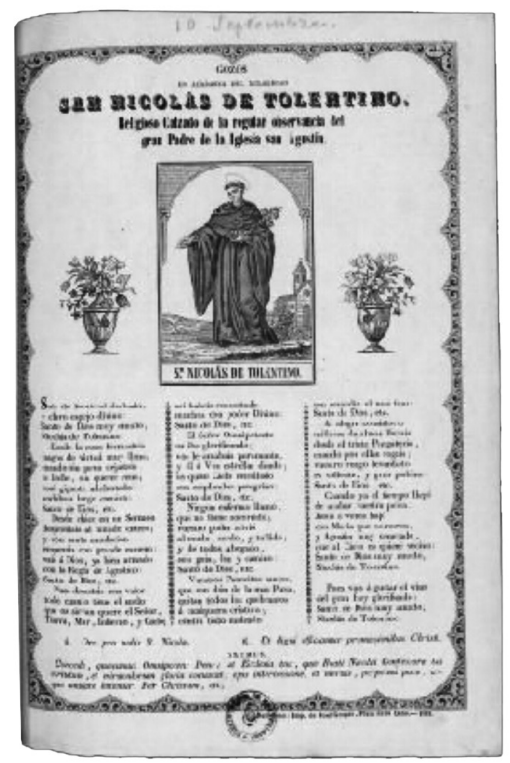

1853, editor José Gorgas.

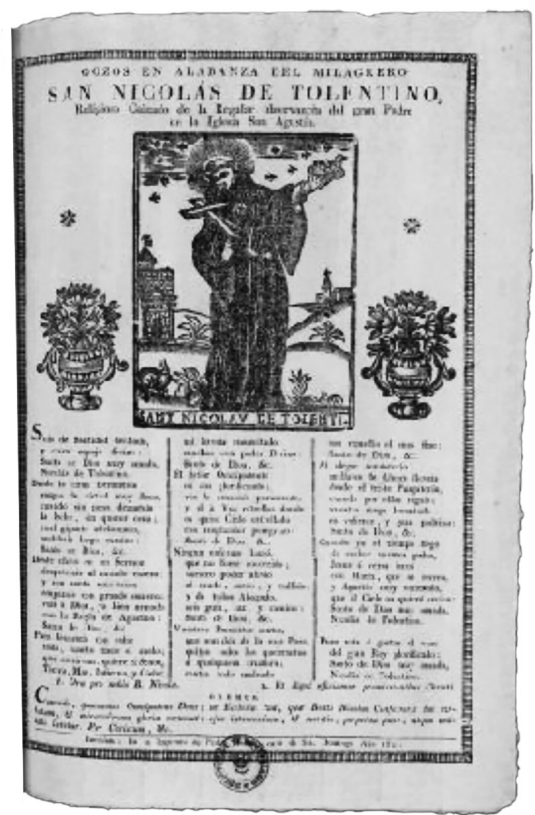

1825, editor Pere Maimo

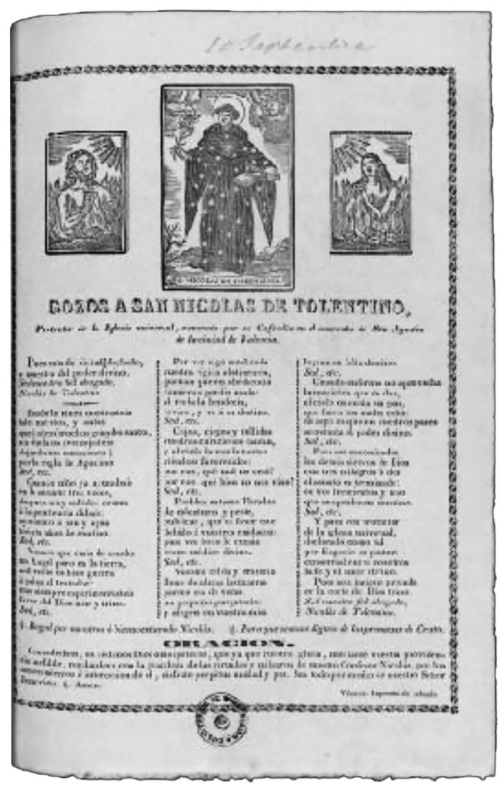

Siglo XIX, editor Laborda. 


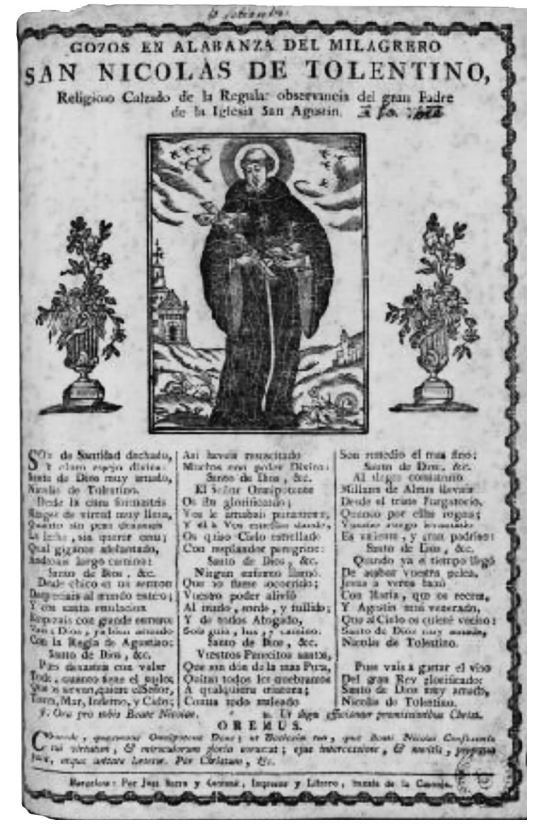

Siglo XIX, editor Joan Serra i Centené.

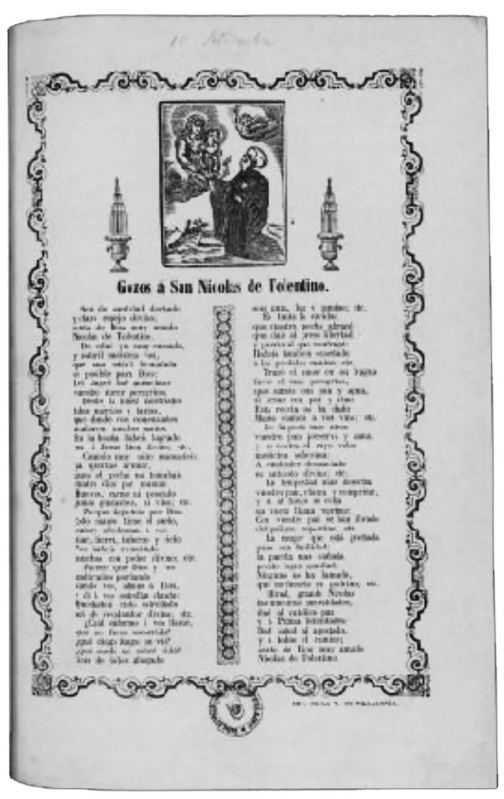

Siglo XIX, editor Viuda de Villalonga.

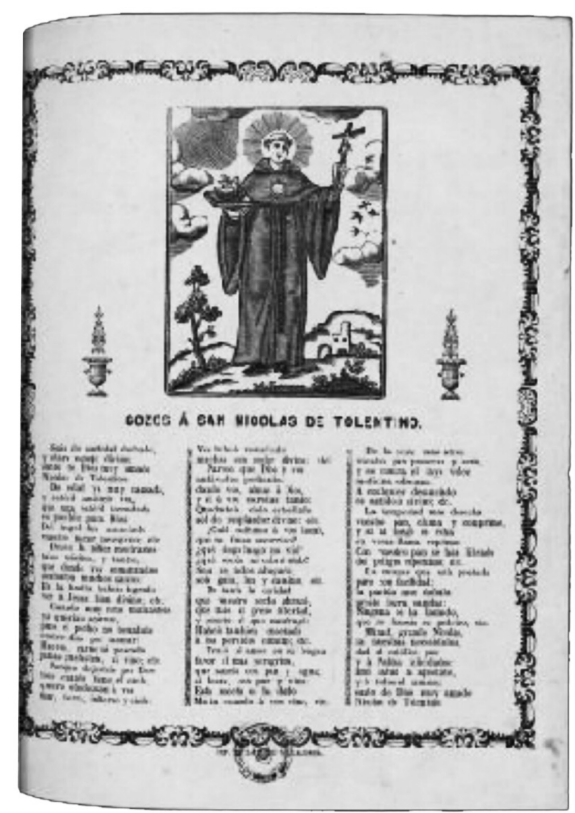

Siglo XIX, editor Viuda de Villalonga.

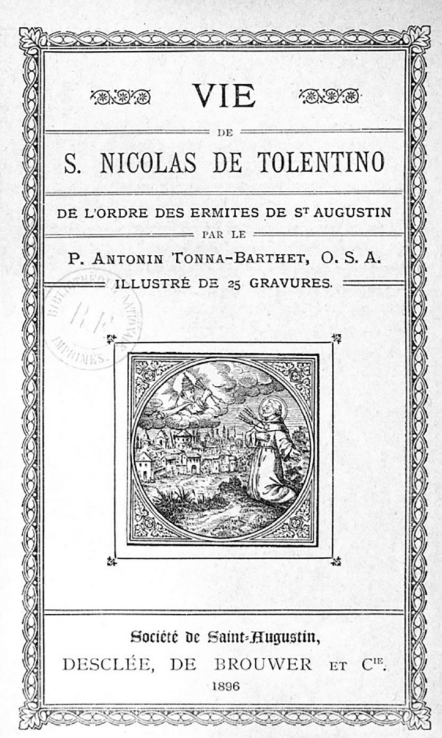


Es curioso que todavía en 1884, en Manila, en la Imprenta de C. Valdezco, viera la luz una bilingüe Novena del milagroso S. Nicolás de Tolentino y modo de hacerla, para alcanzar de Dios por su intercesión los favores que desean, traducida del español al ilocano por D. Adriano Encarnación. Secuela de viejos misionerismos barrocos, porque en Filipinas impusieron los evangelizadores agustinos un culto muy intenso (y plurilingüe) al santo, hasta el punto de que dieron su nombre, en 1621, a una región, y después a unos cuantos lugares y templos.


Pagroadin ti quinasingpetino, Nirdiosen á sarming ti tirigmo:
Pasaym ti Dios a Sumbo,
Nicolis de Tolcntino.
Idi ubingea pay a bassit
Napnoancan iti quinasingpet,
Trocmot dica impirpirit
Idi suso quencat nadis;
Casca gigante ti pardásmo
A nagyigna iti clulanmo.
Pisayam ti Dios, cli,
Idii ubingci pay nangngegeno
$T$ i sermon, nuet idin indianmo
Daytoy lubong nga mangiculbo,
'Tá nagservican iti Dios niga Apo;
Pinilim ngarud at jommo
Ti ulidán ni Agustino.
Prgayalit ti Dios, etc,
I.jnicudam á sibibilerg
Anin i cacon toy a naed
Nagservida á sisasaklit,
Jagá, 'Taan, Infierno, quen L_anğit;
Adú met ti jinagungarmo
Iti quinabileg ti Yjosmo.
Pagaym ti Divs. ct.

Un ejemplo tan interesante como exótico de los milagros que en tierras filipinas se atribuyeron a San Nicolás de Tolentino es éste que nos ofrece una crónica escrita entre 1803 y 1806 :

Lo primero que hallamos digno de notarse fué la iglesia de San Nicolás, que fabricaron los chinos en honor de este Santo, porque dicen que un caimán acometió á un sangley,y habiendo invocado el patrocinio de San Nicolás de Tolentino, el caimán se convirtió en piedra. Hasta el día de hoy se enseña en la otra banda del río una piedra que, haciendo muchas reflexiones é imaginándose uno un caimán muy vivamente, se le asemeja algo dicha piedra; yo creo que el milagro sólo estuvo en la fantasía del chino. Sin embargo, los chinos hacen todos los años 
una fiesta á este Santo, y llevan más de diez quintales de cera de ofrenda todos los años, lo que fué causa de que el párroco de Pásig pusiese pleito al prior de Guadalupe pidiendo que se le entregase la iglesia. El Arzobispo cortó el pleito, agregando la gente que vive aquí y en Guadalupe al pueblo de San Pedro Macatí, y mandando derribar la iglesia y llevando el Santo á Guadalupe, donde los chinos prosiguen celebrando su fiesta todos los años, con comedia chinica y muchas ofrendas de candelas á San Nicolás, a quien muchos de ellos miran más como un ídolo que como un Santo (Martínez de Zúñiga, 1893: I, p. 211).

La Aldea de San Nicolás (Gran Canaria), Pontedeume (A Coruña), Almonacid de la Sierra (Zaragoza), Marinaleda (Sevilla), Adra (Almería) y unos cuantos pueblos españoles más conservan en sus geografías topónimos, imágenes, cultos y fiestas relacionados con San Nicolás de Tolentino, igual que los hay en México - impresionantes las danzas del llamado toro de petate que en honor del santo celebran en Ometepec, en el estado de Guerrero (Martínez Ayala, 2001)_, El Salvador, Costa Rica, Colombia, Bolivia, Argentina, Chile y otros países de América.

Lo justo sería decir que, en realidad, casi no hay templo de la orden agustiniana en que no se venere alguna imagen del santo, aunque no todas han dado lugar a tradiciones o a fiestas sustantivas. Como es imposible el repaso de la gran variedad de milagros atribuidos y de cultos en honor de San Nicolás de Tolentino que han llenado la geografía hispana durante siglos, me limitaré a dar cuenta de un suceso prodigioso que acaeció supuestamente en 1743 en el pueblo mexicano de Zitlala, cercano a Chilpancingo, la capital del actual estado de Guerrero, en el que perdura hoy la veneración del santo:

Desde esta cabecera y pueblo de Chilapa a la de Zitlalá hay tres leguas de distancia. Su rumbo al norte. Su temperamento, caliente. Tiene 175 tributarios enteros. El trato que tiene es hacer puntas y petates y siembra de maíz para su manutención. No hay más calidad de gente que los indios. La administración espiritual es doctrina de agustinos.

Hay en la iglesia de este pueblo la milagrosa imagen del señor San Nicolás Tolentino, que por su intercesión ha obrado Dios Nuestro Señor muchos milagros, porque le dan el título del Santuario de San Nicolás de Zitlalá. El origen y tradición, según me he informado del Muy Reverendo Padre Maestro fray José González Carreto, cura ministro por su merced, de dicha doctrina, los pardos que vivían en los cortijos en la costa del mar del Sur, teniendo gran devoción con el santo pasaron a la ciudad de Puebla de los Ángeles a mandar hacer una hechura del Santo, y teniendo noticia que un religioso agustino del convento de dicha ciudad era buen escultor fueron a verlo para que la hiciera, la que tenía ya hecha y colocada 
en la portería del convento y habiéndoles agradado se la compraron y metieron en un cajón para traerla. Y habiendo caminado hasta dicho pueblo de Zitlalá hicieron allímansión y queriendo el día siguiente seguir su viaje fueron a levantar el cajón para ponerlo sobre la mula en que venía, lo que no les fue posible por haberse hecho el cajón tan pesado que no pudieron fuerzas humanas moverlo, y en vista de tal prodigio dieron cuenta al cura de esta cabecera, por tocarle en aquel entonces la administración de dicho pueblo, con cuya noticia pasó él y habiendo experimentado la gran dificultad de levantar el cajón, dichos pardos suplicaron al cura cantase una misa (como lo hizo) para ver si por este medio se podían llevar al santo. Lo que no pudieron conseguir, por mantenerse el cajón con el peso referido. Con cuya maravilla dichos pardos desistieron de su intento, hicieron donación de la santa imagen al referido pueblo de Zitlalá por ellos y por todos sus descendientes. Y luego in continenti se hizo el cajón tan ligero que con facilidad lo llevaron al templo. Abrieron el dicho cajón, sacaron al santo y lo colocaron en el altar mayor. Y los referidos pardos hicieron promesa de venir todos los años a visitarle y entrar en rodillas en su templo, como lo hicieron aquellos tiempos y lo han continuado todos sus descendientes hasta el presente, alabando a Dios Nuestro Señor por los prodigios que obra su omnipotencia en sus santos (Relacionesgeográficas, 1988: I, p.55).

No contamos con espacio para desentrañar ahora el patrón narrativo -el de la imagen sagrada que insiste en quedarse en determinado lugar- de este tipo de milagro, que es uno de los que de manera más insistente se ha asociado a la traslación de imágenes en todo el mundo católico. ${ }^{1}$ Dejemos simplemente anotado, pues, que tiene, además, viejísimas raíces precristianas:

Admete estuvo en funciones de sacerdotisa durante cincuenta y ocho años. Pero al morir su padre tuvo que huir de Argos y se refugió en Samos, llevándose la imagen de la diosa, confiada a sus cuidados. En Samos encontró un antiquísimo santuario, de Hera, fundado en otros tiempos por los léleges y las ninfas. Allí depositó la estatua.

Mientras tanto, los argivos, inquietos por la desaparición de la imagen, encargaron a unos piratas tirrenos que saliesen en su busca. Esperaban también que los de Samos harían a Admete responsable de la conservación de la imagen y la castigarían si era robada. Como el templo de Samos no tenía puertas, a los piratas les fue muy fácil apoderarse de la estatua; pero al intentar hacerse a la vela, les resultó imposible poner el barco en movimiento. Comprendieron, pues, que la diosa quería quedarse en

\footnotetext{
${ }^{1}$ Al respecto véase Pedrosa, Kalzakorta y Astigarraga, 2009.
} 
Samos. Así, depositaron la sagrada imagen en la orilla, y le ofrecieron un sacrificio. Admete, que se había dado cuenta de la desaparición de la imagen, alarmó a los habitantes, los cuales se pusieron a buscarla por todas partes. Acabaron encontrándola, abandonada, en la playa, pues los piratas habían partido. Imaginando entonces que la diosa había ido allí por sí misma, la ataron con tiras de mimbre. Al llegar Admete, la desató, la purificó y volvió a consagrarla, pues había sido mancillada por el contacto de manos humanas; luego la restituyó al templo. En recuerdo de ello, todos los años los habitantes de Samos celebraban una fiesta, durante la cual se llevaba la estatua de Hera a la playa, se volvía a consagrar y recibía ofrendas.

Pausanias atribuye el traslado de la Hera argiva desde Argos a Samos, no a Admete, sino a los Argonautas (Grimal, 1997, s.v. Admete).

\section{LA CASA ENDEMONIADA Y EL SUDOR DEL SANTO de Cazalla, 12 Al 18 De SePtiembre de 1693}

Entre los milagros atribuidos a San Nicolás de Tolentino que mayor resonancia alcanzaron estuvo el exorcismo que obró supuestamente su imagen, que se veneraba en el convento de San Agustín de Cazalla de la Sierra, en Sevilla, el 12 de septiembre de 1693. Seguramente más por lo espectacular del caso - el exorcismo de una casa estruendosamente endemoniada ante un pueblo aterrorizado- que porque se tratase de un milagro más notable que otros - las resurrecciones, por ejemplo- de los que se asociaban al santo.

El caso es que, casi de inmediato, en el mismo año en que ocurrió el suceso y en el siguiente fueron impresos varios pliegos de cordel que daban cuenta de él y lo exaltaban. El primero parece que fue una Relacion verdadera, delsingularprodigio, que la Magestad de Dios ha obrado en la Milagrosa Imagen de su Glorioso Siervo San Nicolàs de Tolentino, que se venera en la Iglesia de el Convento de San Agustin, de la villa de Cazalla de la Sierra, firmada por Francisco Silvestre, impresa en Sevilla por Tomás López de Haro en 1693, y reimpresa en Cádiz, por la Viuda del Alférez Bartolomé Núñez de Castro, en 1694. El tal Francisco Silvestre parece que se dio muchísima prisa en imprimir su relación, para sacar partido seguramente del impacto que levantaría la nueva del impresionante exorcismo.

Muy poco después fue impreso el pliego que hemos elegido reproducir en esta ocasión, ya que la larga extensión de cada una de las composiciones evocadoras del caso, que tienen además argumentos muy parecidos entre sí, disuade de la 
transcripción de todas ellas. Se halla en el Fondo Antiguo de la Biblioteca de la Universidad de Sevilla, bajo la signatura A 111/014(03). Tiene seis páginas (la segunda en blanco), está fechado "en la Ciudad de Granada este Año de 1694", y contiene un extenso romance "compuesto por Don Phelipe Santiago Zamorano", dedicado a la persona que costeó la impresión, "Don Pedro Mon-Real [...] Mayordomo fervorosíssimo del dicho S. Nicolás de Tolentino", que se veneraba “en el Sagrado Convento del Señor San Augustín de la Villa de Cazalla”, en Sevilla.

No es mucho lo que sabemos acerca del autor del romance, Felipe Santiago Zamorano, excepto que fue poeta que estuvo en activo en Granada en las tres décadas finales del siglo XVII. El subtítulo de uno de los folletos que llevaban su firma decía que en 1698 era "Hermano de la Divina Aurora" de Granada. En aquella ciudad, sobre todo, y también en Sevilla y en algún otro lugar fueron impresos pliegos y folletos muy breves y deleznables con algunos de sus poemas de circunstancias, que le solían encargar eclesiásticos, notables o gremios, para celebrar determinados sucesos religiosos o civiles. ${ }^{2}$ El que un cliente de Sevilla le hiciese llegar hasta Granada la solicitud de que compusiese un romance noticiero en verso sugiere que pudo gozar de algún renombre en toda Andalucía. Algún crítico ha identificado, sin demasiado fundamento, a Zamorano como de Murcia,

\footnotetext{
2 El primer folleto suyo que tenemos fechado, en 1679, es un Romance verdadero donde se da cuenta de los varios efectos que causo la contagiosa epidemia en Granadada [sic], este año de 1679. Otras obras suyas conservadas, siempre en folletos de escasas páginas, son una Descripcion poetica heroica, de la singular, y católica victima, que le consagro a la Virgen de la Antigua, en su Assuncion su siempre venerada Hermandad de Escrivanos del Numero de Granada, Martes 16 de agosto, Año de 1689, siendo su mayordomo don Alonso Cobo Peinado; una Descripcion poetica de las festivas demostraciones, y lucidissima mascara que hizo la Nobilissima ciudad de Granada, assistida de su muy Ilustre, y politica Maestrança, por el felicissimo casamiento de Carlos II con Mariana de Neuburg, lunes 19 de septiembre de 1689; un Panegyrico metrico heroico, al assumpto que consagrò à las respectosas Aras de Maria SSMA en su sacro-santo bulto de las Lagrimas colocado en el convento de San Antonio Abad de Granada [1690]; un Compendio metrico de la fiesta que le consagrò à la Virgen Ssma. de la Antigua en su Assuncion soberana su Hermandad de Escrivanos del Numero de Granada, domingo 16 de agosto de este año de 1693, Siendo su Mayordomo D. Diego de Zayas Castillo; una Metrica relacion, de las segundas Fiestas Reales, que celebrò la Ciudad de Granada, por la salud de Carlos Segundo, aplicandose el producto, para la fabrica del Templo de $N$. Señora de los Dolores en San Phelipe Neri: Hizieronse Iueves 22 de Noviembre de 1696; una Laudatoria en hacimiento de gracias a MariaSantma del Pilar de Zaragoza, pues por sus auxilios reconocen los Gremios de Granada aver quedado libres de la penosa Opression, y Pleyto de seis años, obteniendo Sentencia à su favor [1697]; un Compendio de la magnifica pompa, con que se coloco la Imagen de la Emperatriz de los Angeles, con titulo de la Aurora, en el templo de señor S. Gregorio el Betico, Convento de Clerigos menores de Granada: Celebrise à ocho de Mayo de 1698: a expensas, y solicitud de su Hermandad, de quien es Hermano mayor Juan Ximenez de Carvajal: dedicado al reverendissimo P. Joseph del Peral por D. Phelipe Santiago Zamorano, Hermano de la Divina Aurora. Sin fecha fueron publicadas una Relación verdadera, y curioso romance de la Batalla Nabal, trovado a lo Divino, haciendo Christo, nuestro Redemptor, y Maestro al Principe Don Juan de Austria, y Luzbel al Turco; y unas Glossas para repetir cantando en los quinze misterios del Santissimo Rosario de la Concepcion de la Reyna de los Angeles.
} 
y hay noticias de que escribió una pieza teatral acerca de la batalla de Lepanto que llevaba el título Triunfos del Sol alemán contra la Luna otomana. ${ }^{3}$

El "romance verdadero" del "prodigio" de "la milagrosa Imagen" de "San Nicolás de Tolentino" impreso en 1694 es, acaso, su obra más interesante de entre las que han llegado hasta nosotros. No tanto por su arte poética, que resulta bastante tosca, como por lo fascinante del caso que describe: un milagro que había tenido lugar supuestamente el año antes, en la semana del 12 de septiembre de 1693, en el pueblo sevillano de Cazalla, cuando una imagen de San Nicolás de Tolentino había sido sacada en procesión para exorcizar una casa abandonada de la que durante cinco días estuvieron saliendo estruendos y piedras diabólicos, proyectados contra el convento agustino, que tuvieron amedrentado a todo el pueblo. Después de obrar aquel portento, declaraba el romance que estuvo la imagen del santo sudando prodigiosamente dos días más.

Conozcamos, antes de entrar en detalles, el romance de Zamorano, con su décima introductoria — que da a entender que el mayordomo Monreal le envió una primera "prosa" del milagro por correo, y que por correo devolvió Zamorano su composición en verso-, su aparatoso preámbulo y su sorprendente desarrollo:

\footnotetext{
3 Véase la edición que Pérez Gómez, en el Tomo Segundo de su Literatura Murciana de Cordel, 1960, hizo de las Glossas para repetir cantando en los Quince Misterios del Santissimo Rosario por D. Felipe Santiago Zamorano. Rezaba así su introducción: "Don José Pío Tejera y don Justo García Soriano incluyeron en la Biblioteca del Murciano, con ciertas reservas, suponiéndole oriundo de nuestras tierras por sus apellidos, a Felipe Santiago Zamorano, coplero popular del siglo XVII. Nosotros, aun sintiendo muy fuertes dudas sobre tal suposición y casi discrepando totalmente del parecer de tan distinguidos bibliógrafos, hemos querido incorporar a esta colección alguna obrilla de este pretendido paisano nuestro, por si acaso fuese fundada la creencia de estos dos investigadores de obras de murcianos o impresas en nuestra región. Felipe Santiago Zamorano fue un poeta bastante humilde cuyo nombre suena poco en los catálogos bibliográficos. Tejera y García Soriano lo encontraron en el repertorio de don Cayetano Alberto de la Barrera, donde se le cita fugazmente como autor de una pieza teatral, Triunfos del Sol alemán contra la Luna otomana, cuyo tema es la célebre batalla de Lepanto. Este asunto de la famosa batalla naval donde se cubrió de gloria el hermano bastardo de Felipe II debió de ejercer bastante atracción sobre la musa de nuestro supuesto coterráneo, pues nosotros conocemos un romance suyo, a lo divino, de aquel acontecimiento, que fue ya publicado en nuestro Romancero del Almirante de la mar don Juan de Austria".
} 




ROMANCE VERDADERO, DONDE SE DEclara el singular, inaudito, y estupendo prodigio, que la Magestad de Dios obró en la milagrosa Imagen de su glorioso siervo San Nicolás de Tolentino, venerada en el Sagrado Convento del Señor San Augustin de la Villa de Cazalla, para fervorizar a los Fieles a la devoción.

Imprimióse a costa de Don Pedro Mon-Real, Mayordomo fervorosissimo del dicho S. Nicolás de Tolentino, en la Ciudad de Granada este Año de 1694.

Compuesto por Don Phelipe Santiago Zamorano.

A Don Pedro Mon-Real.

\title{
DÉZIMA.
}

\author{
El milagro del glorioso \\ Nicolás de Tolentino, \\ Mon Real, si en prosa vino, \\ ya va en verso decoroso;
}


porque siendo fervoroso

Mayordomo en tal empleo,

según en la lista leo

a Sevilla con Fe quieta,

si vino por la estafeta,

le volváis por el correo.

Con vna voz misteriosa,

el Artífice supremo,

crió la máquina vella

del azul Olimpo excelso.

Construió el Imperio Sacro

tachonado de luzeros,

corte, donde siempre en paz,

permaneciesse su asiento.

Crió nueve Herarquías

de Ángeles, dulces Orpheos,

que en zítaras argentadas

lo aclamen santo, y perfecto.

Crió Esferas, crió Zonas,

fixando en el firmamento

en exércitos de estrellas,

batallones de reflexos.

Crió los siete Planetas,

colocando al Sol en medio,

Presidente de las luzes

del día, Monarca bello.

Pobló el Zéfiro de plumas,

de Salamandras el fuego,

la tierra de varias flores.

y el mar de pezes diversos.

A su semejanza hizo

en el campo Damasceno

al hombre, y aunque de tierra

quedó hermoso como vn Cielo. 
Y Luzbel, viendo entre enigmas,

entreluzes, y bosquexos,

antes de ser hecho Adán

encarnado al Sacro Verbo.

Revelde, y lleno de embidia

quiso colocar soverbio

sobre los astros de Dios

su silla bárbaro, y ciego.

Pero San Miguel, sacando

la cuchilla, interrumpiendo,

¿Quién como Dios?, lo arroxó

precipitado al infierno.

Arrastando con la cola

el Dragón vano indiscreto,

la tercer parte de estrellas

que su infausta voz siguieron.

Desde entonces Luzifer

quedó enemigo sangriento

de los hombres, por mirarlos,

de lo que él perdió herederos.

Dexando con sus cautelas

en mísero cautiverio

al hombre, siendo vn bocado,

quien puso a sus triumphos freno.

Mas el Verbo, haciéndose Hombre,

lo libró, pues si el precepto

quebrantó Adán en vn árbol

en otro Árbol triunphó el Verbo.

Y viendo Luzbel que Christo

le dio palo con el leño

de la Cruz, contra los hombres

asestó sus tiros fieros.

Las historias están llenas

de los engaños, y enredos

de sus fuertes asechanzas,

y diabólicos pretextos. 
Obrando Dios con sus Santos,

para postrar sus intentos,

milagros esclarecidos,

y singulares portentos.

Y el que oy escribe mi pluma

es vno, tan estupendo,

que compite a quantos se hallan

en los anales del tiempo.

Hecho por San Nicolás

de Tolentino, opulento

archivo de maravillas

como de prodigios centro.

Dando testimonio claro

su vida, y milagros, y esto,

hasta la perdiz lo canta,

haziendo platillos dello.

Oygan pues, de Nicolás,

el prodigio tan sugeto

a la verdad sucedida,

que va a la letra compuesto.

En la Villa de Cazalla,

que tiene su hermoso asiento

en Sierra-Morena, fértil

por su apacible terreno.

A quien con lícitos tratos

la hacen de rico comercio

Gual-Canal, y Costantina,

por ser immediatos Pueblos.

Ay vn Convento sagrado

del Africano Luzero,

que de Mónica, y Patricio,

fue hijo, y Doctor Supremo.

Del Águila de la Iglesia

de San Agustín, con esto,

sin episodios declaro

las glorias deste Convento. 
En cuyo divino Alcázar,

está Nicolás luziendo,

como en su casa, en vn nicho,

que lo enriqueze su ojebto [objeto]

Circuncidada de sus muchos

Milagros, que son inmensos,

pues no caven ya, aunque vengan

como de cera a traerlos.

Próximo al Convento está

un edificio que a miedo

provoca, causando orror

con espantosos efectos.

Inevitable por causa

de oírse en sus apossentos

ruidos escandalosos,

sin ver el motivo dellos.

Sin duda debe de ser,

porque en él se cometieron,

o delitos execrables,

o algún estrago funesto.

Sábado, a los doze días

de setiembre, cuando Fevo

a la antípoda da luzes,

y sombra a nuestro Emisferio.

A las nueve de la noche,

estando todo en silencio,

de rrepente se asustaron

los Religiosos modestos.

Fue la causa vn torbellino

de piedras, que con estruendo

caían sobre las texas,

y paredes del Convento.

Causando pavor, porque

conocido el detrimento,

las menores ofendían

más, y las mayores menos. 
Cinco noches con espanto, nubes de piedra llovieron espesas, como granizos, sobre el sunptuoso Templo.

Quedando todo el texado vna pedrería hecho, sino de piedras preciosas de pedernales groseros.

Alborotóse Cazalla, inquietáronse los pechos queriendo tomar venganza los nobles, y los plebeios.

La lusticia cuidadosa con fiel Católico zelo, hizo grandes diligencias, para castigar los reos.

Huvo varios pareceres, los más doctos discurrieron en el caso, y no se pudo averiguar el sucesso.

Mas el Reverendo Padre F. Gaspar Páez (que es perfecto) Prior del Convento sacro y en todas letras Maestro discurrió que de la casa horrorosa aquellos riesgos salían, y que el demonio causaba tales excessos.

Conjuró una y muchas vezes al enemigo, creiendo que a la fuerza del conjuro huiría a su fúnebre centro.

Mas el pertinaz, rebelde, le estuvo tirando luego más piedras que a San Esteban le tiraron los Hebreos. 
Que el pérfido Satanás

como villano grosero,

estila en tentar con piedras,

aunque sea en el desierto.

Viendo el Prior que no basta

el conjuro, y que proterbo

se estaba a los exorcismo,

a las penas y preceptos,

Le dixo San Nicolás

de Tolentino: muy presto

vendrá a triunphar de tu furia

y a castigar tus intentos.

Y entonces fue la tormenta

de piedras, con más excessos

por donde se conoció

ser espíritu sobervio.

Combocó a toda la Villa

el Prior, y manifiesto

en forma, mostró en Custodia

al Augusto Sacramento.

Dixo Missa en el Altar

de San Nicolás, y luego

en processión fue a la casa

con la asistencia del Pueblo.

Rezando el Santo Rosario

de María, que obra cierto,

por ser devoción de quenta

los prodigios con misterios.

Aquí fue el mayor combate

del infernal comuneros,

pues sobre los que rezaban

arroxó cantos inmensos

cuyas duras municiones

en los seculares dieron,

sin tocar a Religioso

por celestial privilegio. 
Y cuando se rezelaban estragos los golpes fueron como el blando algodón ¡O plumas, raro portento! El prior (como otro Antonio Abad) se puso en el riesgo paratriunphar del demonio con la virtud de su pecho.

Y caiendovn sillar grande a sus pies permitió el Cielo que le ofendiesse, dando admiración el sucesso,

En fin, nuestro Nicolás en procesión entró dentro de la casa, y el demonio huió vencido del puesto.

El Prior y otros testigos fidedignos se subieron por las tapias de la casa vn obscuro vapor denso.

En medio de dos tinajas todos dos golpes oyeron, tan grandes que causó assombro elextrépito violento.

Otros vieron con las luzes de la cera vn gato negro, que al son de una castañeta vailaba el villano fiero.

Otros le oyeron reír, mas para él es muy cierto que fue cosa de risa el ir llorando al infierno.

Quieto el rumor infernal, con San Nicolás volvieron al Convento en processión dando mil gracias al Cielo. 
Y estando el Sacristán solo, después de irse todo el Pueblo se llegó a apagar las luzes, que en la processión ardieron;

Y aunque lo intentó mil vezes no pudo, que más luzieron, y admirado dixo a vozes: "Santo Nicolás, ¿qué es esto?

Miró al Santo, y vio que el rostro sudaba mucho y creiendo que fuesse el agua bendita, que en el conjuro esparcieron,

Lo limpió con reverencia, y visto que iba creciendo el sudor, maravillado dio cuenta al Prelado atento.

El Prior y la sagrada Comunidad acudieron a ver esta maravilla como en claríssimo espejo.

Al rumor de las campanas la Villa llegó corriendo a mirar este milagro auténtico y verdadero.

Y llorando de placer el Prior, con dulce acento entonó el Te Deum Laudamus, Te Dominum confitemur.

Con lágrimas en los ojos todos el cántico oyeron, dándole gracias a Dios por beneficio tan nuevo.

Dos días estuvo el Santo sudando, con tal extremo que caló hasta la capilla, aunque era de terciopelo. 
Por nariz, frente y mexillas sudó, y con grande respeto, en los purificadores por reliquia le cogieron.

Y vngidos con el sudor sanaron muchos enfermos, que el Médico declaró ser el milagroso efecto.

El Vicario de la Villa, Alcaldes, y Cavalleros fueron testigos de vista de tan singular portento.

Calificando el prodigio Cinco Escrivanos discretos de Cazalla, y un Notario, que Fe y testimonio dieron.

Y en la Ciudad de Sevilla en el Sagrado Convento de San Augustin se guarda en su archivo con respeto.

En poder de F. Francisco de San Nicolás Supremo Procurador en Provincia de Andaluzía y sus Reynos.

Esta mararavilla rara, este prodigio estupendo, aumenta de Nicolás las glorias y los trofeos.

Quedando toda Cazalla alegre y libre de riesgo que Luzifer ofrecía con repetidos estruendos.

Todo Christiano (si quiere triunphar) de los siete cuellos de la Idra ponzoñosa por donde respira incendios, 


\author{
ármese con el escudo \\ de San Nicolás, traiendo \\ su estampa consigo, que es \\ triaca contra veneno. \\ Y con ello, y con guardar \\ los Divinos Mandamientos, \\ iremos con Nicolás \\ de Tolentino a los Cielos.
}

Muy en síntesis, el romance de Zamorano da cuenta de los "ruidos escandalosos" que cierto día comenzaron a salir de un edificio próximo al convento de San Agustín, en Cazalla. Acaso "porque en él se cometieron, / o delitos execrables, / o algún estrago funesto", según suele rumorearse de las casas que el vulgo cree encantadas o endemoniadas por algún crimen sin castigo o sin redención que allí se cometería. Puede ser interesante señalar que el antiguo convento de San Agustín no alberga hoy ninguna comunidad religiosa ni ninguna imagen de san Nicolás de Tolentino, sino que es sede del ayuntamiento de Cazalla de la Sierra. Hay en el pueblo, en cualquier caso, una calle que lleva el nombre de San Nicolás de Tolentino, en una de cuyas esquinas está engastada una composición cerámica, fechada en 1778-muy posterior a los sucesos de 1693 - , que retrata al santo.




El romance de Zamorano dice, en concreto, que fue un "sábado, a los doze días / de setiembre" del año anterior, es decir, de 1693, "a las nueve de la noche" para más señas, cuando se produjo "vn torbellino / de piedras, que con estruendo / caían sobre las texas" del convento, procedentes de la casa vecina. Y así, "cinco noches con espanto, / nubes de piedra llovieron”, dejando el tejado del convento lleno "de pedernales groseros". El prior agustino del convento, F. Gaspar Páez, "conjuró una y muchas vezes / al enemigo", y con ello logró sólo agravar la furia de los proyectiles, sobre todo en el momento en que amenazó al diablo con invocar la ayuda de San Nicolás de Tolentino.

Decidió el prior pasar entonces de las palabras a los hechos, sacar la imagen del santo del convento y llevarla en procesión hasta la casa endemoniada, con todo el pueblo "rezando el Santo Rosario". Pero sucedió que "sobre los que rezaban" empezaron a caer "cantos inmensos", que golpearon sobre los seculares, "sin tocar a Religioso”. Lo sorprendente es que, además de hacer tan escrupulosa selección de sus víctimas, no causaron aquellos proyectiles más dolor entre los apedreados que si hubiesen sido "blando algodón" o "plumas". Como si fueran piedras del más allá, que aquí no obrasen efecto. Al fin, cuando la imagen entró en la casa, el demonio "huió vencido", dejando detrás lo que unos creyeron que era "vn obscuro vapor denso", otros un "extrépito violento", otros "vn gato negro, / que al son de una castañeta / vailaba el villano fiero" — acotación inesperadamente humorística一, mientras que, en fin, "otros le oyeron reír". El caso es que la casa quedó, de acuerdo con el romance, liberada para siempre de su infernal presencia.

Mas no cesaron ahí los milagros del santo: cuando aquella noche el sacristán intentó "apagar las luzes, / que en la processión ardieron” descubrió que no era capaz de apagarlas, y entonces "miró al Santo, y vio que el rostro / sudaba mucho". "Dos días estuvo el Santo/ sudando" un líquido que "en los purificadores / por reliquia le cogieron". "Y vngidos con el sudor / sanaron muchos enfermos". De modo que los milagros de san Nicolás fueron en realidad cuatro: el exorcismo de la casa endemoniada, la imposibilidad de apagar las luces de la iglesia, el sudor del santo, y las sanaciones que procuró a muchos enfermos.

El poeta concluye su relación recomendando a los devotos que, si aspiran a no ser nunca vencidos por las asechanzas del demonio, lleven siempre consigo el preventivo de la estampa del santo.

Puede resultar muy instructivo comparar la información que ofrece el pliego de 1694 con la evocación de los mismos sucesos que ofrece una Vida de San Nicolás de Tolentino, de la Orden de San Agustin, Protector de la Iglesia Universal, Abogado de 
las Almas del Purgatorio, escrita en francés por el P. Antonino M. Tonna-Barthet, de la misma Orden, y traducida al castellano por el P. Pedro Corro, agustino recoleto, que he manejado en una edición publicada en Madrid, por la Librería de Gregorio del Amo, en 1901. La cual declara, en lo que concierne al milagro de Cazalla, que "la relación que acabamos de hacer se lee en una Memoria, sumamente interesante, impresa en Cádiz en 1694. Reprodújola el Padre Ricardo, que murió Obispo de Cagliari, en una Vida de San Nicolás impresa en Madrid, á sus expensas, en 1701”. Inexacto el subtítulo, que convierte en "Ricardo" a quien se apellidó "Sicardo". De todo ello se puede concluir, en fin, que, apenas "acaecido" el suceso que empezó a perturbar el 12 de septiembre de 1693 al pueblo de Cazalla, vio la luz una primera crónica impresa de la que se escindieron, en ramas y con injertos diversos, versiones en prosa o en verso que se mantuvieron más o menos fieles a parecidos guiones argumentales:

En Cazalla de la Sierra, en España, había una casa deshabitada, próxima al convento de Padres Agustinos, la cual era frecuentada por los demonios. El sábado 12 de Septiembre de 1693, á eso de las nueve de la noche, salió de aquella casa un ruido formidable, seguido de una granizada de piedras que cayeron por tres horas consecutivas sobre el techo de la iglesia y sobre el del monasterio, repitiéndose el mismo fenómeno en los tres días siguientes. Hallábase todo el mundo tan aterrado, que el Prior del convento, P. Gaspar Páez, creyó necesario emplear cuanto antes las preces de los exorcismos contra un hecho tan extraordinario. Dirigióse á la capilla, que caía enfrente de la casa endemoniada, y comenzó los exorcismos en medio de un diluvio de piedras, que continuaban arrojando los espíritus infernales; piedras que, sin embargo, á nadie herían ni dañaban. "Espíritu soberbio, dijo entonces el santo religioso, no quieres rendirte á los sagrados exorcismos, mas yo te haré obedecer por la intercesión del gran Nicolás.'A este nombre, que les era tan odioso, redoblaron los demonios sus ataques, y tal cantidad de materiales lanzaron sobre la iglesia, que los asistentes huyeron despavoridos. No queriendo el P. Gaspar ceder al espanto, hizo anunciar para el siguiente día una solemne y pública procesión, en la cual sería llevada una imagen del Taumaturgo de Tolentino. Al otro día, después de la Misa cantada, dirigiéronse los religiosos y el pueblo á la casa ocupada por Satanás, rezando fervorosamente el Rosario, á fin de obtener la protección de la Virgen Madre de Dios. Conforme la procesión iba llegando, dejóse otravez percibir el ruido, que fué después cesando ante las precesy la imagen de Nicolás, y retumbando por fin dos gritos espantosos, como señal de la marcha definitiva de los espíritus infernales, alejáronse de allí para no volver jamás. La imagen del Santo, á la cual se atribuyó el milagro, fué conducida á la iglesia con extraordinaria pompa, y rodeada de numerosas luces, sencillos testigos de un piadoso agradecimiento. Dicha imagen, según uso de la época, estaba formada de un cuerpo de cera, vestido de tela, como una persona viva. 
Sucedió, después de esto, que, habiéndose quedado solo en la iglesia el sacristán para apagar las candelas, no pudo conseguirlo, y, á pesar de su habilidad y sus esfuerzos, éstas siguieron encendidas. Lleno entonces aquél de admiración, quedóse mirando ála milagrosa imagen, y exclamó: “¿Qué es eso, ¡oh mi Santo glorioso!?”. Aproximóse después, y vió con estupor que la cara de Nicolás estaba cubierta de gotas que parecían de agua. Creyendo en un principio que sería el agua bendita, que habría caído durante los exorcismos sobre la santa imagen, quiso borrarlas con un pañuelo; mas, cosa extraña, á medida que iba él frotando, nuevas y abundantes gotitas aparecían corriendo por la cara, semejantes á las gotas de sudor.

Ante este prodigio, apresuróse el sacristán á llamar á los otros religiosos, los cuales, habiéndolo presenciado, abrieron las puertas de la iglesia y tocaron las campanas llamando al pueblo, que acudió inmediatamente en tropel. Tres veces se vió inundada la imagen, y los médicos que vinieron á examinar el hecho de cerca dijeron unánimemente que la efusión de sudor era semejante á la que sale de los cuerpos animados y llenos de vida. Renovóse el prodigio el jueves siguiente á las cinco de la tarde, y al otro día á las doce de la mañana; mas ahora todavía era más extraordinario y más completo, pues el sudor corría de su mano izquierda, en la que tenía un libro.

Empapóse enteramente el vestido que cubría la imagen de esta agua maravillosa, la cual fué, para los enfermos y achacosos, fuente de curaciones y de salud. Cualquiera tela mojada en aquella agua obtenía al instante el milagro solicitado por aquellos que hacían uso de ella.

La relación que acabamos de hacer se lee en una Memoria, sumamente interesante, impresa en Cádiz en 1694. Reprodújola el Padre Ricardo, que murió Obispo de Cagliari, en una Vida de SanNicolás impresa en Madrid, á sus expensas, en 1701. Imposible nos sería hacer siquiera mención de los demás milagros de nuestro Taumaturgo; es demasiado grande su número (Vida de San Nicolás de Tolentino, pp. 325-328).

Entre los milagros innumerables a los que se refiere el autor de esta Vida de San Nicolás de Tolentino publicada en español en 1901 hay uno que resulta especialmente significativo, porque exalta otro caso de exorcismo que opera, en ciertos aspectos, en oposición al anterior: la víctima es ahora una mujer poseída que ha de hacer el camino hasta el lugar en que se encuentra la imagen del santo, en vez de la imagen del santo la que ha de desplazarse hasta el lugar endemoniado:

La lucha entre Nicolás y Satanás, tan terrible y persistente durante la vida del Santo, continuó después de su muerte. La invocación de su santo nombre, el homenaje tributado á sus imágenes, las oraciones hechas ante sus reliquias, tenían suficiente eficacia para arrojar de las casas, ó bien del cuerpo de los poseídos, á los demonios que los habitaban. 
Vamos á citar algunos ejemplos notables. Una religiosa de San Ginés, llamada Sor Filipuccia, hallábase poseída del demonio. Durante sus accesos tomaba su rostro feísimo aspecto, y, contrayéndose sus ojos con una expresión espantosa, lanzaba aullidos de lobo, mugía como los bueyes, ladraba como los perros, y ofendía gravemente al pudor y la modestia con sus palabras obscenas. Llegaba su demencia hasta invocar frecuentemente al inmundo Belial con otros demonios para que la defendiesen de los tiranos que ella se figuraba ver ante sí durante sus dolores. Por espacio de cinco años ejerció Satanás el más absoluto dominio sobre esta desgraciada, la cual, por fin, un día, en uno de sus raros momentos de lucidez, tuvo el pensamiento de encomendarse al Taumaturgo de Tolentino y de decirle: “'Oh bienaventurado Nicolás! Si vos me sanáis, yo prometo ir á visitar vuestro sepulcro con los pies descalzos y con las manos atadas". Alegres y consoladas al oír estas palabras las religiosas del convento, uniéronse á su Hermana para implorar el socorro del monje agustino, y, obtenido permiso del abad de Clairvaux, entregaron la poseída á una persona de confianza con encargo de que, vallándola durante el trayecto, la condujese á Tolentino. Ni una vez siquiera en todo este tiempo se atrevió el demonio á perturbar á Filipuccia. Apenas ésta hubo llegado ante las preciosas reliquias y orado fervorosamente ante ellas, huyó el demonio sin ruido y para siempre, mientras que la poseída se hallaba entregada á un sueño profundo y reparador. Estaba, pues, enteramente curada (Vida de San Nicolás de Tolentino, p. 320).

En relación con el prodigioso sudor del santo, se puede añadir todavía una información relevante: la imagen del convento agustino de Cazalla no sudó en 1693 porque sí, sino porque tal modalidad de milagro debía de estar por entonces tradicionalmente asociada a sus imágenes. Lo prueba una crónica de 1698, casi contemporánea de los sucesos de Cazalla, que daba cuenta de cómo sudó otra imagen de San Nicolás de Tolentino que había sido instalada por los agustinos en un pueblo remotísimo de las islas Filipinas:

Tiene el ministerio de Panay cinco visitas: la primera es Mayong, con la advocación de San Jerónimo, con otra pequeña visita llamada Ypión, su titular San Lorenzo. Este pueblo fue antiguamente muy rico en oro, porque lo sacaban los indios del río con lavaderos, pero instigados de las vejaciones que recibían de algunos Alcaldes Mayores lo han dejado de sacar, queriendo más vivir con pobreza que padecer semejantes trabajos. La segunda es Aranguen, con la advocación de San José. Tiene este pueblo un río de agua muy saludable que sana de cualquiera enfermedad contagiosa al que en él se baña. La tercera visita se llama Sibará, su advocación San Nicolás de Tolentino. La cuarta, que está en el monte, Dumingding, su advocación N. P.San Agustín, y es pueblo de mucha gente y temple muy benigno. La quinta 
visita es Juisan, pueblo cercano al mar y de mucha gente, es patrón de su Iglesia S. Nicolás de Tolentino, cuya imagen de escultura es hermosa, devota y ha obrado Dios por el Santo muchos milagros, sanando a diversos enfermos que se le han encomendado. Muchas veces la han visto sudar, especialmente cuando los naturales de aquel pueblo, olvidados de la obligación de cristianos, han hecho alguna supersticiosa obra de las que acostumbraban en los tiempos de su gentilidad, que es algún maganito o sacrificio al demonio. En tiempos antiguos aconteció que un indio desalmado, viendo que el santo descubría semejantes delitos, fue a la iglesia y le dio una bofetada; pero no quedó su atrevimiento sin castigo, porque en aquel mismo día le llevó un caimán la mano derecha, quedando él vivo para reconocer su culpa y ser pregonero continuo de su delito (Gaspar de San Agustín, 1975, p. 534).

\section{Lo más curioso es que la misma crónica filipina de 1698 atribuía también a una imagen de san Sebastián, vecino de san Nicolás en aquellos remotos pagos, sudores parecidos:}

Porque habiendo visitado aquella islay reconocido la distancia de los ministerios de Dumalag y Batan, encargó se fundase uno de nuevo en el río de Mambusao, en el pueblo de Tepec, como se ejecutó, con la advocación de Santa Catalina Mártir. Su partido se compone de más de mil doscientos tributarios, porque es fertilísimo de arroz. Compónese de cinco visitas; la una el río abajo, al promediar el camino, que se llama Signa, su advocación San Juan Bautista, y es pueblo de mucha gente. Las otras están en los montes; la una a la subida del mismo río y se llama Tinga, con la advocación de San Nicolás de Tolentino; otra nombrada Hagnaga, su titular Santo Tomás de Villanueva; otra más adentro del monte y distante de la cabecera, que se llama Hamindang, su patrón San Sebastián, cuya imagen de tallay perfecta escultura que se venera en aquella iglesia es muy antigua y milagrosa, pues muchas veces la han visto sudar y mudar semblante, especialmente cuando los habitadores de aquel territorio han cometido algún desacato contra nuestra santa fe. En cuya comprobación, por fin de agosto de 1675, un viernes, comenzó a sudar y lo continuó con tanta abundancia en otros, que haciendo pesquisa el Padre ministro de Mambusao, Fr. Alonso Escos, descubrió cierta conspiración de los indios sugeridos del demonio, y ante Pedro de Villanueva se hizo información de este milagro. Sucedióle a dicho Padre el año de 1674 que habiendo traído a la iglesia una india llamada Sabina, de quien se había apoderado el demonio porque no quería ser su Babaylana o Sacerdotisa, al tiempo de tocar a Sanctus la atormentó el demonio de suerte que fue preciso sacarla de la iglesia; y habiéndola conjurado y reconociendo la resistencia del demonio, la hizo llevar otro día al tiempo de celebrar misa; y volviéndose a ella con la Hostia consagrada, la preguntó si conocía, creía, temía y adoraba aquel Señor. Respondió con mansedumbre que 
sí, y que quería confesarse, como lo ejecutó con muchas lágrimas, y se vio libre no sólo de la opresión del demonio sino también de otra enfermedad de llagas que padecía (Gaspar de San Agustín, 1975, pp. 718-719).

Cabe añadir algo más acerca de los apedreamientos diabólicos que sufrió supuestamente el convento de San Agustín de Cazalla en 1693. Resulta que fray Antonio de Fuentelapeña, en su excéntrico ensayo acerca de El Ente dilucidado. Discurso único novisimo en que muestra hay en la naturaleza animales irracionales invisiblesy cuálessean (1676), dejó escritos unos cuantos interesantísimos párrafos acerca de tal especie de fenómenos. Partían sus disquisiciones de las que había hecho otro fraile demonólogo, Salvador Ardevines Isla, en otro tratado más estrafalario aún, si cabe: la Fábrica universal y admirable de la composición del mundo mayor, a donde se trata desde Dios, hasta nada, y del menor, que es el hombre. Enseñase en el todo lo que ay en el Mayor, trayendo su origen desde Dios, como principio, y bolviendo a el mismo como a último fin en quien resplandece su divina unidad, y la de todas las cosas (1621).

El caso es que en la Instancia octava de El ente dilucidado evocaba Fuentelapeña, siguiendo en ocasiones a Ardevines, unos cuantos casos que tienen ingredientes que nos resultarán familiares. En particular un apedreamiento acaecido en otro convento de San Agustín, aunque aquella vez fuera el de Huesca y no el de Cazalla: ¿guardarían los demonios apedreadores alguna inquina especial contra los conventos agustinianos? Nos interesarán también directamente algunos casos más en que se veían involucrados "estos mismos duendes (que el dicho [Ardevines] llama demonios) [que] muchas veces echan piedras por los tejados y en las calles sin hacer daño". Acotación densamente informativa, que nos ilustra sobre la equiparación, que debía ser frecuente en la época, de duendes y demonios, sobre la creencia de que los apedreamientos sobrenaturales se libraban muchas veces en las alturas de los tejados, y sobre la convicción de que aquellas piedras fantasmagóricas, como las que serían arrojadas en Cazalla en 1693, no causaban daño a quienes eran golpeados por ellas:

642. El licenciado Ardevines refiere por cosa llana y averiguada que los duendes caseros hacen mil visiones, y que a una señora de Aragón, persona de crédito, le oyó él dicho contar los engaños que uno de dichos duendes le hacía, entre los cuales fue uno, que una vez le puso a esta señora un palo empañado, como una criatura muerta dentro de una arca cerrada con llave. Y que en la ciudad de Huesca, el año mil seiscientos uno, huvo otro duende en el convento de San Agustín que hacía música con las flautas del órgano, y otras invenciones. Y el mesmo depone, como testigo de oido (que llaman inmediato) haberle sucedido que, 
estando leyendo en Severino Boecio, a un paso de distancia de adonde él estaba, dieron grandes golpes dentro de un banquillo y que, llegándose el tal Ardevines a reconocer el banquillo, no halló cosa alguna en él, ni en la parte en que estaba, ni en toda la pieza había cosa que pudiese hacer dicho ruido; y que esto era en tiempo que se hacían semejantes ruidos en dicha casa y otras cosas tan extraordinarias, que no se podía atribuir a causa natural corpórea.

643. Y añade más que a otra señora le sucedió semejante caso en el mismo banquillo, en el cual oyó uno como trueno, de que quedó desmayada por algún tiempo, sin otras burlas que le hizo en otras ocasiones [...]

645. Y concluye diciendo que estos mismos duendes (que el dicho llama demonios) muchas veces echan piedras por los tejados y en las calles sin hacer daño, bailan y hacen otros visajes, mueven truenos, relámpagos, hacen caer rayos, recias lluvias, granizos y vientos, sed sic est, que dichos efectos se pueden atribuir a causa corpórea y son propios de los demonios; ergo etc.

646. Respondo que de dichos argumentos nada puede seguirse contra nuestra conclusión, pues cuando el efecto que se alega por instancia, es de calidad que no puede atribuirse a causa natural corpórea, en tal caso decimos, que el tal efecto no es efecto de los duendes, sino de algún espíritu diabólico o angélico (conforme el efecto fuere), y cuando el tal efecto es de calidad que no exceda las fuerzas de un agente corpóreo invisible en parte, y sólo visible, secumdum quid, puede atribuirse sin inconveniente a los que llamamos duendes, y que son el objeto único de nuestra cuestión; y así nada puede seguirse de dicha instancia y efectos que se alegan en ella contra nuestra resolución [...]

655. Alodelastempestades, rayos, etc. respondo, quelos que muevenyconcitan dichastempestades son demonios pero no duendes, y asínibil contra nos, y que los demonios puedan conmover grandes tempestades vehementes, y turbulentos vientos, que derriben casas, etc. consta de lo que se lee acerca de Job, I, y de lo que dice la Iglesia en los conjuros que por el contrario las tempestades, de relámpagos, y granizos [...] Todo lo cual se hade entender que lo hacen, $\mathrm{o}$ permitiéndolo Dios, o como ministros suyos y de su divina justicia, porque todos ellos tienen el poder limitado, y así no pueden arrojar rayos, apedrear, ni hacer otros mayores daños de su propio motivo, como lo define el Concilio Bracarense, en que presidió el papa Honorio I, porque de otra suerte, presto acabaran con el universo y destruyeran todos los hombres, como lo dice Clemente Romano [...

931. Opondrás lo octavo: los duendes hacen violencias, y cosas que arguyen fuerza; verbi gratia mudan platos, tiran piedras, y dan golpes, y abruman a los que duermen echándoseles encima; lo cual no pudieran hacer si fueran animales invisibles. Lo uno, porque así consta a paridad del ácaro y arador: y lo otro, porque la invisibilidad de cuerpo arguye debilidad de fuerzas en él. Luego los duendes, antes parecen ser espíritus que cosa corpórea; ergo etc. 
932. Respondo lo primero que aunque los duendes fueran espíritus, habían de obrar lo dicho mediante algún cuerpo que tomasen, pues suelen aparecerse en él; del cual cuerpo, como sea invisible, y sutil, debe discurrirse del mismo modo, y así puede volverse contra los que objetaren dicha objeción, como deja conocerse de suyo.

933. Respondo lo segundo que el aire tiene cuerpo invisible, y bien sutil, y con todo eso derriba casas, arranca piedras y hace otras violencias que arguyen mucha fuerza. Luego no implica en un cuerpo sutily débil la fuerza. Luego etc. (Fuentelapeña, 2007,pp. 261-262 y 306). ${ }^{4}$

\section{MÁS CASAS ENDEMONIADAS Y MÁS SANTOS SUDOROSOS}

Las creencias acerca de casas endemoniadas o encantadas, en general, y de casas en las que "apedrean", en particular, han formado parte del imaginario más arraigadamente popular en muchos tiempos y lugares. Y las relativas a santos que sudan (o que lloran) de manera prodigiosa han tenido cierto predicamento también en toda la geografía católica. No podemos, en las páginas finales de este trabajo, convocar tantos paralelos como sería fácil reunir de ambos tópicos; en trabajos futuros esperamos poder desgranar muchos más. Pero el detalle de alguno sí nos permitirá entender dentro de un contexto clarificador, para cerrar este trabajo, el suceso -o más bien los relatos que surgieron al calor de él- que ocurrió supuestamente en Cazalla en septiembre de 1693.

Evocaremos, por ello, un prodigio acaecido supuestamente a finales del siglo XIX en tierras filipinas, tan apegadas, según hemos comprobado, al culto de San Nicolás de Tolentino. Aunque en esta ocasión no fuera la imagen del santo, sino una cruz, el agente de la expulsión de los demonios lapidadores:

Tienen gran devoción á la santa Cruz, y han experimentado en ocasiones el amparo de ella. Estando unos cristianos una noche rezando la doctrina en su casa (como solían) comenzaron de fuera, á apedrearles la casa y hacerles grande ruido, y tirarles cuanto al derredor de ella había. Saliendo varias veces á saber quien les hacía mal, no vieron persona alguna: y volviéndoseá recoger, volvían de fuera a inquietarlos. Entendiendo ser ardid del demonio, perseveraron en rezar, confirmándose en la fé con la persecución que les hacía; y para defenderse dél arbolaron una cruz delante de la casa. Desde entonces no sintieron cosa que les inquietase (Chirino, 1890, p. 184).

\footnotetext{
4 Sobre lacuestión de los duendes barrocos en generaly de las varias modalidades de travesuras que hacían, incluidos los apedreamientos, sigue siendo fundamental el artículo de Caro Baroja, 1944.
} 
En cuanto al sudor milagroso, he elegido como contrapunto del que sufrió la imagen de San Nicolás de Tolentino en Cazalla otro que aquejó, también en tierras coloniales, concretamente en la ciudad de Tunja - que se halla en la actual Colombia-, a un lienzo que representaba a otro santo conquistador y proselitista, San Francisco de Borja, de acuerdo con lo que rememoraba una crónica de 1684:

Dezía el gran patriarca san Ignacio que, aunque la Iglesia devía tanto a san Francisco Xavier por las innumerables almas que le ganó en el Oriente, devía más la Compañía a san Francisco de Borja, por lo mucho que la estendió y la acreditó en España y en todo el mundo, siendo vicario general destas provincias y las de Indias; y si a san Gregorio el Magno le damos título de apóstol de Inglaterra no porque estubo en aquel reino, sino por los muchos predicadores que embió a él para ganarle, a san Francisco de Borja, que introduxo en Indias la Compañía y embió tantos missioneros para la conversión de su mucha gentilidad, bien podemos llamarle apóstol de las Indias Occidentales y dezir que lo es muy especialmente de las reducciones del Marañón, en que tiene su advocación la ciudad que ha sido el presidio de aquella conquista evangélica y el lugar de refugio de todos sus missioneros; de donde empezó a conseguirse la christiandad que veremos después conseguida en tan escondidas montañas, a que abrió puerta un descendiente suyo y de su nombre, el príncipe de Esquilache, don Francisco de Borja, siendo virrey del Perú. Y no atendió menos a la conversión de gentiles otro descendiente suyo, el presidente de Santa Fe en el Nuevo Reino de Granada, don Iuan de Borja, procurando la conquista del Chocó y otras naciones; y en tiempo de su presidencia tubo mucho misterio aquel averiguado milagro de un lienço de San Francisco de Borja que sudórepetidas vezes en la ciudad de Tunja; sudor que podemos pensar lo causó la fatiga que representaba con el peso de tanta gentilidad como ay en Indias y que estaba a su cuidado y protección el que se convirtiesse por sus hijos (Rodríguez, 1990, p. 168).

Los sudores milagrosos son parientes inequívocos del llamado don de lágrimas, cuya casuística ha estudiado en un artículo magistral María Tausiet (2009, pp. 167-202). El sudor es signo, obviamente, de cansancio tras realizar una labor trabajosa - y las de exorcizar casas y conquistar continentes debían serlo-, y las lágrimas revelan la piedad de unos santos a cuyas imágenes les han sido tradicionalmente asignadas, como responsabilidades principales, las de proteger a los católicos y expandir su religión; pero también las de mostrarse cercanos, empáticos, inteligibles para sus fieles, haciéndose partícipes de sus emociones, dolores y debilidades. 


\section{BiBLIOgRAFÍA}

Cabrera de Córdoba, L. (1857). Relación de las cosas sucedidas en la corte de España desde 1599 hasta 1614. Madrid, España: Imprenta de J. Martín Alegría.

Caro Baroja, J. (1944). Los duendes en la literatura clásica española. Algunos mitos españoles. Madrid, España: Editora Nacional.

Chirino, P. (1890). Relación de las Islas Filipinas y de lo que en ellas han trabajado los padres de la Compañia de Jesús. Manila, Filipinas: Imp. de Esteban Balbás.

El Santo milagroso augustiniano S. Nicolas de Tolentino, sus excelencias, vida, muerte y milagros. Poema heroico, repartido en veinte libros (1628). Madrid, España: Imprenta Real.

Fuentelapeña, A. de (2007). El ente dilucidado. Discurso único novísimo que muestra hay en naturaleza animales irracionales invisibles y cuales sean. Ed. Arsenio Dacosta. Zamora, España: Instituto de Estudios Zamoranos Florián de Ocampo. Grimal, P. (1997). Diccionario de mitología griega y romana. Barcelona, España: Paidós. Reed. 1997.

Martínez Ayala, J. A. (2001). ¡Epa! Toro prieto. Los toritos de petate. Una tradición de origen africano traída a Valladolid por los esclavos de lengua Bantú en el siglo XVII. Morelia, México: Editorial Instituto Michoacano de Cultura.

MartíneZ DE ZúÑIGA, J. (1893). Estadismo de las Islas Filipinas, o mis viajes por este país. Ed. W. E. Retana. 2 vols. Madrid, España: Imp. de la Viuda de M. Minuesa. Noticias de la Corte (1893). Ed. Antonio Paz y Melia. Madrid, España: Imprenta de M. Tello.

Pedrosa, J. M.; Kalzakorta, J., y Astigarraga, A. (2009). Gilgamesh, Prometeo, Ulises y San Martín: Mitología vasca y mitología comparada. Ataun, España: Fundación José Miguel de Barandiarán.

PÉrez Gómez, A. (1960). Literatura Murciana de Cordel. 2 vols. [Monteagudo 29, 1960]. Relacion del nvevo prodigio, que se ha visto en el brazo izqvierdo de San Nicolas de Tolentino, de la Orden de San Augustin. Imprimiòse en Napoles, con licencia de sus Superiores. Escriviola Andres Colicchia; al mvy R.P. el Padre Maestro Fr. Antonio Carboner, Doctor en S. Theologia, y Predicador de la Orden de San Augustin. Agoranuevamente traducida de Italiano, en Castellano (1671). Barcelona, España: Jacint Andreu. Relación distincta, y breve, en la qual se refiere un portentoso milagro, que obrò Dios, por medio del Glorioso S. Nicolás de Tolentino. Svcediò en el estado de Mantva en la Diocessis de Cremona, en vna Villa nombrada Viadana, resucitando vna niña de dos años y tres meses cayda, y ahogada en un profundo poço, à 23 de Junio del año 1711. 
Vino la presente relación impressa en lengua italiana, y se ha traducido fielmente en idioma Español, en la Excellentissima Ciudad de Barcelona, Reimpressa con las devidas aprobaciones, y licencias de los Superiores (1712). Barcelona, España: Joan Jolis. Relaciones geográficas del arzobispado de México, 1743, (1988). 2 vols. Ed. Francisco de Solano. Madrid, España: CSIC.

Riber A, F. de (1631). Vida de Sant Nicolas de Tolentino, y discurso cuaresmales. Sevilla, España: L. Estupiñan.

Rodríguez, M. (1990). El Marañón y Amazonas. Historia de los descubrimientos. Ed. Ángeles Durán. Madrid, España: Alianza.

Rueda, L. de (1992). Paso de Polo y Olalla, negra. En Pasos. Ed. José Luis Canet. Madrid, España: Castalia.

San Agustín, G. de (1975). Conquistas de las Islas Filipinas. Ed. Manuel Merino. Madrid, España: CSIC.

SiCA Rdo, J. (1701). Viday milagros del Glorioso San Nicolás de Tolentino, con una devota novena al santo. Madrid, España: Manuel Ruiz de Murga.

Tausiet, M. (2009). Agua en los ojos: El Don de lágrimas en la España Moderna. En M. Tausiet y J. S. Amelang (coords). Accidentes del alma: Las emociones en la Edad Moderna (pp. 167-202). Madrid, España: Abada.

Torres, B. de (1974). Crónica Agustina. Ed. Ignacio Prado Pastor. Lima, Perú: Imprenta de la Universidad Nacional Mayor de San Marcos.

Villegas, A. de (1998). Fructus sanctorum y quinta parte del Flossanctorum. Ed. José Aragüés Aldaz. En Memorabilia: Boletín de Literatura Sapiencial Medieval 2. Recuperado de http://parnaseo.uv.es 